\title{
Material-Driven Textile Design (MDTD): A Methodology for Designing Circular Material-Driven Fabrication and Finishing Processes in the Materials Science Laboratory
}

\author{
Miriam Ribul $^{1, *}$, Kate Goldsworthy ${ }^{2}$ and Carole Collet ${ }^{3}$ \\ 1 Materials Science Research Centre, Royal College of Art, London SW7 2EU, UK \\ 2 Chelsea College of Arts, University of the Arts London, London SW1P 4JU, UK; \\ k.goldsworthy@chelsea.arts.ac.uk \\ 3 Central Saint Martins, University of the Arts London, London N1C 4AA, UK; c.collet@csm.arts.ac.uk \\ * Correspondence: miriam.ribul@rca.ac.uk
}

Citation: Ribul, M.; Goldsworthy, K.; Collet, C. Material-Driven Textile Design (MDTD): A Methodology for Designing Circular Material-Driven Fabrication and Finishing Processes in the Materials Science Laboratory. Sustainability 2021, 13, 1268. https:// doi.org/10.3390/su13031268

Received: 21 December 2020

Accepted: 20 January 2021

Published: 26 January 2021

Publisher's Note: MDPI stays neutral with regard to jurisdictional claims in published maps and institutional affiliations.

Copyright: (c) 2021 by the authors. Licensee MDPI, Basel, Switzerland. This article is an open access article distributed under the terms and conditions of the Creative Commons Attribution (CC BY) license (https:/ / creativecommons.org/licenses/by/ $4.0 /)$.

\begin{abstract}
In the context of the circular economy, materials in scientific development present opportunities for material design processes that begin at a raw state, before being introduced into established processes and applications. The common separation of the scientific development of materials from design intervention results in a lack of methodological approaches enabling designers to inform new processes that respond to new material properties. This paper presents the results of a PhD investigation that led to the development and application of a Material-Driven Textile Design (MDTD) methodology for design research based in the materials science laboratory. It also presents the development of the fabrication of a textile composite with regenerated cellulose obtained from waste textiles, resulting from the MDTD methodology informing novel textile processes. The methods and practice which make up this methodology include distinct phases of exploration, translation and activation, and were developed via three design-led research residencies in materials science laboratories in Europe. The MDTD methodology proposes an approach to design research in a scientific setting that is decoupled from a specific product or application in order to lift disciplinary boundaries for the development of circular material-driven fabrication and finishing processes at the intersection of materials science and design.
\end{abstract}

Keywords: design methodology; materials science; textile recycling; regenerated cellulose; composites; fabrication; material design; transdisciplinary; interdisciplinary; circular economy

\section{Introduction}

A strong focus on the exploration of materials in design and materials science is placed on finding viable alternatives to materials in existing processes and reducing their environmental impacts [1-3]. Scientific advancements are promising factors to enable sustainable change in how we use natural resources $[4,5]$. These specialist processes, however, are normally removed from a design practice. Technical material developments take place in a scientific context where, according to Küchler, in the nineteenth century, "malleable" materials and new production technologies removed design from the processes of industrial material manufacture [6]. Miodownik describes the start of a complex materials revolution in the twentieth century, where discovery and development became a scientific activity separated from the arts, and argues for a methodological approach in which artists get to know materials through artistic processes [7]. In the context of the complexity of materials science, Manzini was the first to suggest that a material should be described not for what it "is", but for what it is "used for" and to consider, "how does it work" [8] (pp. 55-63). Based on this, Karana et al. ask what a material "expresses to us, what it elicits from us, and what it makes us do" [1] (p. 35). This aligns with Tim Ingold's argument that within the realms of anthropology, art, archaeology and architecture, we need a practice 
"with" and not "of" materials [9] (p. 8). He argues against a hylomorphic model where, "practitioners impose forms internal to the mind on a material world 'out there", , but instead concludes that making is a "process of growth" in which materials are "active" participants [10] (pp. 20-21). Attempts to integrate design in scientific material research have led to a new generation of material engagement: materials-by-design [6]. In this approach, the product end-use comes first, and newly developed materials are made to fit technological requirements. The field of circular material innovation would benefit from design-integrated experimentation "with" materials in scientific development in order to develop new materials and processes fit for the circular economy.

There is a methodological gap for design research based in the materials science laboratory that was established as part of the PhD research of this paper's first author, using a literature and a practice review [10]. Acknowledging that the scientific development of materials takes place in dedicated materials science laboratories, we argue that designers can expand materials science research by integrating design research tools at the onset of the material development. The "Krebs Cycle of Creativity", developed by Oxman, places design and science opposite each other in a coordinate plate and connects them through art or engineering [11]. The interactions between these four domains in this cycle evidence exchanges as "currency" and not a methodological approach as such. Whilst a designscience practice was pioneered by Buckminster Fuller in 1927 [12], historically, efforts have been placed on transforming the design method into a scientific one [13]. Karana et al. [1], Peralta [14], Driver et al. [15], and Rust [16] have listed a range of projects that support the collaboration between the disciplines of design and materials science. However, product designers are still determining how to operate in the scientific domain [14,15]. Many design methodologies place ideas and inspiration [17], a vision [18], or design thinking [19,20] at the start of the design process. For example, the Design Council's "double diamond design process model" is represented by areas of divergent and convergent processes in two consecutive "diamond"-shaped stages [17] (p. 6). However, the double diamond methodology is defined by a material selection in the second diamond [21], which is a method also used in engineering [22], in order to apply the material to specific end products or applications. Table 1 summarises the constituent elements of existing material design methodologies in interdisciplinary collaboration: the driver, the methods employed at the start of the research, the setting in which the research takes place, its outcomes, and the mode in which the practice takes place. Examples of material design methodologies in interdisciplinary collaborations are limited. These interdisciplinary projects take place individually in separate domains of the laboratory or design studio [1,23-25], or are facilitated in neutral settings, such as workshops in large-scale projects [26-29]. Moreover, even if designers work from within the materials science laboratory, the practice with materials remains within the disciplinary domain of design or science, and the outputs of these interdisciplinary collaborations are mostly new material developments or applications. A shift from a product or material development focus to concentrating on processes with materials would invert the common design methodology beginning with an envisioned product and application, as it is found in a materials-by-design approach. The context of circularity in which regenerated cellulose materials obtained from waste textiles are chemically recycled is a recent disciplinary domain which would promote such investigation.

Table 1. Drivers, action steps, setting, outcomes, and practice in interdisciplinary material design methodologies.

\begin{tabular}{|c|c|c|c|c|c|}
\hline Author and Year & $\begin{array}{l}\text { Title (If Named) and } \\
\text { Driver }\end{array}$ & First Action Step & Setting & Outcomes & Practice \\
\hline $\begin{array}{c}\text { Thong and Jackson, } \\
2011 \\
{[30]}\end{array}$ & $\begin{array}{l}\text { Product Design } \\
\text { Driven Research }\end{array}$ & $\begin{array}{c}\text { Specification of } \\
\text { material performance } \\
\text { criteria }\end{array}$ & Not specified & $\begin{array}{l}\text { Commercial } \\
\text { application of new } \\
\text { materials }\end{array}$ & $\begin{array}{l}\text { Interdisciplinary } \\
\text { collaboration }\end{array}$ \\
\hline $\begin{array}{c}\text { Rognoli et al., } 2015 \\
\text { [24] }\end{array}$ & DIY-materials & Material sampling & $\begin{array}{l}\text { Design studio } \\
\text { practice }\end{array}$ & Material samples & $\begin{array}{c}\text { New materials for } \\
\text { design }\end{array}$ \\
\hline
\end{tabular}


Table 1. Cont.

\begin{tabular}{|c|c|c|c|c|c|}
\hline Author and Year & $\begin{array}{c}\text { Title (If Named) and } \\
\text { Driver }\end{array}$ & First Action Step & Setting & Outcomes & Practice \\
\hline $\begin{array}{c}\text { Karana et al., } 2015 \\
\text { [1] }\end{array}$ & $\begin{array}{l}\text { Material Driven } \\
\text { Design (MDD): } \\
\text { Materials experience }\end{array}$ & $\begin{array}{c}\text { Technical and } \\
\text { experiential } \\
\text { characterisation } \\
\text { through tinkering }\end{array}$ & $\begin{array}{l}\text { Design studio } \\
\text { practice }\end{array}$ & $\begin{array}{l}\text { Material experiences } \\
\text { within a material or a } \\
\text { product }\end{array}$ & $\begin{array}{l}\text { (Material) design } \\
\text { practice }\end{array}$ \\
\hline $\begin{array}{c}\text { Härkäsalmi et al., } \\
2017 \\
{[31]}\end{array}$ & $\begin{array}{l}\text { Technical and } \\
\text { perceptual qualities } \\
\text { of materials }\end{array}$ & $\begin{array}{l}\text { Design-driven } \\
\text { process in a } \\
\text { material-based } \\
\text { approach defined by } \\
\text { an example } \\
\text { application }\end{array}$ & $\begin{array}{l}\text { Iterative prototyping } \\
\text { in unspecified setting }\end{array}$ & $\begin{array}{l}\text { Application-driven: } \\
\text { acoustic interior } \\
\text { elements }\end{array}$ & $\begin{array}{c}\text { Interdisciplinary } \\
\text { research } \\
\text { (design-science } \\
\text { collaboration) within } \\
\text { the disciplinary } \\
\text { domain }\end{array}$ \\
\hline $\begin{array}{c}\text { Niinimäki et al., } 2018 \\
\text { [27] }\end{array}$ & $\begin{array}{c}\text { Properties of new } \\
\text { materials }\end{array}$ & $\begin{array}{l}\text { Presentations and } \\
\text { assignments } \\
\text { (hands-on play with } \\
\text { similar materials) }\end{array}$ & $\begin{array}{l}\text { Interdisciplinary } \\
\text { workshops }\end{array}$ & $\begin{array}{l}\text { Interdisciplinary } \\
\text { materials } \\
\text { development: } \\
\text { material properties; } \\
\text { application areas; } \\
\text { design ethics }\end{array}$ & $\begin{array}{l}\text { Interdisciplinary: } \\
\text { materials science, } \\
\text { synthetic biology, } \\
\text { design and art }\end{array}$ \\
\hline $\begin{array}{c}\text { Barati et al., } 2019 \\
\text { [25] }\end{array}$ & Smart materials & $\begin{array}{l}\text { Prototyping material } \\
\text { demonstrators }\end{array}$ & Design studio & $\begin{array}{l}\text { Collaborative } \\
\text { material } \\
\text { development }\end{array}$ & $\begin{array}{l}\text { Interdisciplinary: } \\
\text { design, materials } \\
\text { science }\end{array}$ \\
\hline $\begin{array}{l}\text { Tubito et al., } 2019 \\
\text { [26] }\end{array}$ & $\begin{array}{l}\text { Design-driven } \\
\text { Material Innovation } \\
\text { (DDMI): Materials } \\
\text { and their technology }\end{array}$ & $\begin{array}{l}\text { Envisioning material } \\
\text { and design scenarios }\end{array}$ & $\begin{array}{l}\text { Materials R\&D in } \\
\text { parallel to material } \\
\text { conceptualisation; } \\
\text { workshop setting for } \\
\text { the collaboration }\end{array}$ & $\begin{array}{l}\text { New applications } \\
\text { and systems of } \\
\text { materials }\end{array}$ & $\begin{array}{l}\text { Interdisciplinary: } \\
\text { design practice, } \\
\text { materials science, } \\
\text { manufacturing, end } \\
\text { user research }\end{array}$ \\
\hline
\end{tabular}

Regenerated cellulose obtained from waste textiles has existed since 2012, and only a few design prototypes have been produced from scientific research to demonstrate its potential applications, whilst these interdisciplinary partnerships are difficult to map when they are not documented [10]. Regenerated cellulose is here produced in a nontoxic chemical recycling process in which post-consumer cotton is dissolved before it can be regenerated in a coagulation bath and spun into new fibres [4,32-34]. The scientific developments with regards to regenerated cellulose obtained from waste textiles suggest its potential to replace environmentally impactful cotton fibres [35-38]. Practice-based textile design and materials science collaborations in this field create artefacts to demonstrate the viability of regenerated cellulose to substitute materials in established processes such as knitting, weaving, or 3D printing at the product, finishing, and textile processing stages, from yarn to fabric, in the existing textile value chain, as evidenced in the outputs of these projects [39]. In this approach that aims for a like-for-like replacement of environmentally impactful materials, design research cannot intervene into the scientific development of regenerated cellulose to inform new textile processes. On the other hand, the scientific achievement of being able to regenerate cellulose from end-of-life textiles with non-toxic chemicals results in a material that is suitable for the circular economy. Regenerated cellulose materials sit within the context of the bioeconomy for industries that use biological materials, enabling a circular bioeconomy [40]. Averting the use of landfills for postconsumer textiles through chemical recycling technologies would keep resources within a closed loop. However, scientific research states that cellulose-based materials cannot be infinitely recycled while maintaining the same quality $[38,41]$. This may provide new challenges for textile processes in the circular economy, since recycled regenerated cellulose materials have a decreased polymer length that would make this material unsuitable for the established textile value chain. This suggests that circularity requires the need for intervening with the raw materials at hand before these are manufactured, processed, or engineered for a specific process or application, as well as textile processes that both enable circularity and respond to the context of circular recycling.

This paper presents a Material-Driven Textile Design (MDTD) methodology for design research based in the materials science laboratory that facilitates design intervention at 
the first stage of scientific research, in order to develop new circular processes "with" the material. The methodology is the result of a PhD research investigation with the hypothesis that textile design research intervening in the scientific development of regenerated cellulose materials can inform new textile processes inscribed within the circular economy. The design research was structured around three research residencies in materials science laboratories (2016-2018): the first two residencies with Dr Hanna de la Motte, the focus area manager for Circular Materials Ecosystems (AoI Material Transition) and a researcher at the Division of Materials and Production (Department of Chemistry, Biomaterials and Textiles; unit Fiber Development), which was then the Bioeconomy Division (Cellulose-based Textiles Section; Biorefinery Unit) at RISE Research Institutes of Sweden (RISE) [42,43], and the third residency at the Department of Bioproducts and Biosystems of Aalto University's School of Chemical Engineering, in Finland. Each residency corresponds to one of the three action steps described in the methodology, with the first residencies followed by two studio practice stages, structuring the activity into stages of action and reflection [10]. The three stages of the MDTD methodology corresponding to three research residencies in materials science laboratories were developed at the outset of the research. Section 2 outlines the methodological approaches that underpin the development of the methodology. Sections 3-5 then describe the three action steps of exploration, translation and activation, and how the methods in each stage developed through practice, leading to a new circular material-driven process for textile composite fabrication with regenerated cellulose. Section 6 discusses the MDTD methodology in the context of material design methodologies in interdisciplinary research and the challenges of its constituent elements when it is applied by other designers and to other materials. Finally, the conclusion in Section 7 evaluates how design research based in the materials science laboratory can establish new courses of action for the scientific development of new circular and regenerated materials.

\section{The Material-Driven Textile Design (MDTD) Methodological Framework}

This section describes the methodology developed in a textile design context, but refers to "material design processes", "material design situations" and "material design visions", which include textiles. Figure 1 illustrates the three action steps of exploration, translation, and activation in the author's Material-Driven Textile Design methodology, in which a raw material is the starting point of the research and the results are textile or material artefacts resulting from the new material design processes. Figure 1 also shows which disciplinary domain informed each action step: the material tests in the exploration stage are informed by materials science, represented by a diamond shape; both materials science and design equally inform the material experiments in the translation stage; therefore, the diamond shape merges with an ellipse; the new material design processes in the activation stage are then based on the design vision, represented by an elliptical shape. The designer tests, experiments and designs new material design processes in each action stage by introducing design techniques into the materials science laboratory. These processes result in circular artefacts that are compatible with the raw material stage after recycling. The designer can consequently repeat the methodology to develop processes that respond to the modified material properties.

The Material-Driven Textile Design (MDTD) methodology is underpinned by the theoretical context of three methodological approaches, which evolved from the following principles for a materials design practice situated in the materials science laboratory: action research and participatory design research for the collaboration with materials scientists to access, observe, and participate in scientific processes; material-driven design for the focus of the methodology on exploring new material design processes, which are decoupled from a specific product or application; and tacit knowledge in a strong design disciplinary background to inform the transdisciplinary, practice-based work with materials in the tools and techniques introduced. 


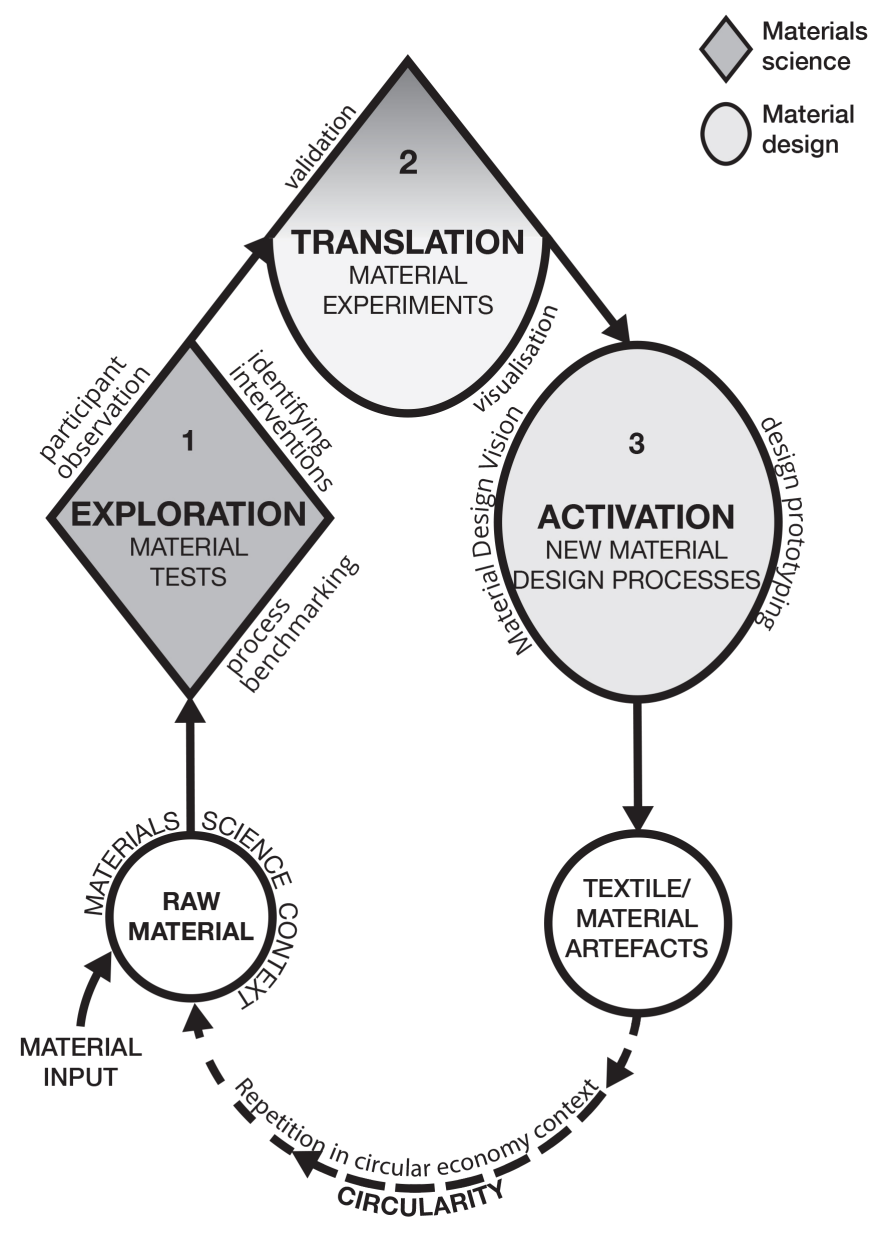

Figure 1. Material-Driven Textile Design (MDTD) methodology [10].

Participatory design in action research can be used to create an equal collaboration with materials scientists. Whereas action research promotes experiments "in the field, rather than laboratory" [44] (p. 18), the field for design research in the MDTD methodology is in fact the materials science laboratory. Action research comes from the social sciences, but instead of research on others, it argues for a critical self-reflection that can take place with others, and therefore focuses on the transformation of practice [45]. The MDTD methodology aims to achieve a change of design practice in a materials science context. This change of practice follows Kurt Lewin's iterative cycles of planning, acting, observing, and reflecting [45]; cycles of action and reflection in constructivist research [46]; and each research cycle can revise the initial plan [47]. Whereas action research can be performed individually, participatory design research evolved with the aim of creating change in society by involving the participants in the research in an equal manner [48-50]. In participatory action research, a cooperative enquiry is a form of research "with" rather than "on" people, where "all the active subjects are fully involved as co-researchers in all research decisions" [49] (p. 145). This methodology can be used for small group research projects, ingraining the transformation of the participants [49]. As the MDTD methodology does not focus on the study of scientists, but on the development of new textile design processes, it can be useful for the development of interdisciplinary collaborative research between individual design and materials science researchers.

The second methodological approach addresses the practice "with" and not "of" materials in their raw state [9] (p. 8), and methods for material-driven design. An approach that puts the material at the start of the design process is "materials driven design", which begins with exploration and experimentation to find new opportunities [21] (p. 282). The "Material Driven Design (MDD) method" of Karana et al. begins with an, "understanding 
of the material" through "tinkering" in order "to understand its inherent qualities, its constraints, and its opportunities" [1] (p. 41), but differentiates itself from other materialdriven approaches by designing for material experiences through a "product and/or further developed material" [1] (p. 10). The mastering of the material through "tinkering" is particularly suitable for materials that are "not fully developed" [1] (p. 41), such as regenerated cellulose obtained from waste textiles. What the MDTD adds to, or replaces in, the MDD method is described through the practice in Sections 3-5.

The third aspect is how tacit knowledge informs the evaluation and progression of the design practice when it is based on craft knowledge such as design techniques. Craft here explores a "flow of activity" [51] (p. 35) and emerges from "embedded knowledge" in "the interplay between tacit knowledge and self-conscious awareness" [52] (p. 50). A recurrent practice with materials leads to tacit knowledge, a specifically intuitive approach that cannot be described in an instruction for others to emulate, but that practitioners can apply to other work. The results of the design practice in the MDTD methodology are analysed with a qualitative assessment of the haptic and visual properties based on tacit knowledge of the disciplinary background. This assessment is formed by actions based on "tacit knowledge", which was first argued by Polanyi to be based on "a rich understanding and knowledge" that is "gained over life time experience, a theory that is increasingly applied to design and artefacts" [16] (p. 77). Tacit knowledge in design is mostly traced back through "reflection-in-action" [46] (p. 49) and becomes evident in the results of processes and techniques such as those introduced into the materials science laboratory in the MDTD methodology, as well as in the manifestation of the "technical", "sensorial", and "aesthetic" character of the resulting materials and artefacts [1] (p. 42).

The next sections describe the methods of the three methodological stages of exploration, translation, and activation in order to illustrate the development of the practice with regenerated cellulose materials in chemical recycling. This research produced two hundred samples, resulting from the experiments in both the materials science laboratory and the studio practice [10]. The following sections document key experiments for each of the action stages towards the development of a new textile composite fabrication process. Whilst experiments were repeated several times for validation, a selected successful sample is included in this paper. Including multiple samples into this paper would hinder an overview of the development of practice through research. The experiments appearing in this paper are numbered according to the corresponding residency, followed by the number of the experiment taking place within each residency.

\section{MDTD Action Step 1: Exploration}

The exploration stage corresponds to the first residency in the materials science laboratory at RISE Research Institutes of Sweden. Latour and Woolgar argue that scientific processes require an observation "in situ" and claim that from a social science perspective [53] (p. 37), the observer needs to select a "theme" to delineate the method [53] (p. 35), which will produce order from the observations. The theme in the design brief for the first residency was, "to explore the specific properties and processes concerned with the production of regenerated cellulose in the science laboratory" at the raw material stage [10] (p. 365). Language barriers in interdisciplinary research were also considered on site and Wilkes et al. [54] and RISE Research Institutes of Sweden [55], outline that tools for collaboration are often required in these spaces. By employing design methods—such as sketchbooks, drawings (Figure 2a), and mapping (Figure 2b) — to document the way in which both the scientist and design researcher were thinking about textile design research from within the context of working in the materials science laboratory together, these tools helped bridge the discipline-specific language and explore visual communication in the residency [42]. 


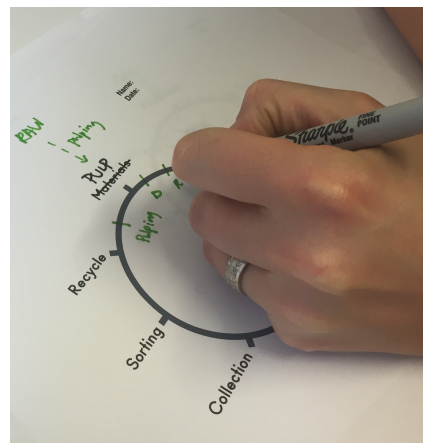

(a)

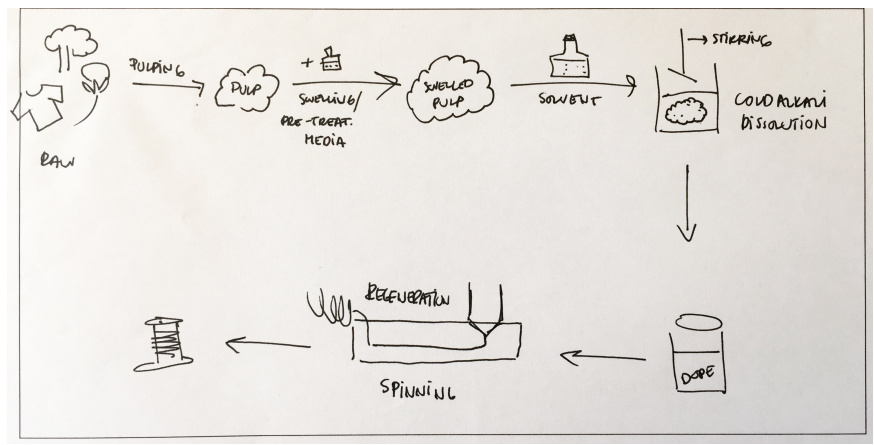

(b)

Figure 2. (a) Drawing of the circular lifecycle of regenerated cellulose obtained from waste textiles; (b) Mapping of the process for cellulose regeneration with the materials scientist.

\subsection{Participant Observation}

This stage observed the existing scientific method for the dissolution of cellulose materials, the scientific analysis of the cellulose dissolution and its suitability in the spinning process, as well as the scientific method for the regeneration of dissolved cellulose in the fibre spinning process. The observation was documented with a sketchbook, photography, diagrams, and process maps, as well as notes and interviews. One key observation was that when fibres do not dissolve or when the properties of the cellulose dissolution change, the raw material may not be suitable for fibre spinning. This informed two directions for the research: whether new textile processes could make use of this otherwise redundant material, and the lab work follows a scientific method in order to spin a fibre from a cellulose dissolution, in which design research cannot intervene experimentally, as it would disrupt the formation of the fibre. A better understanding of the chemical recycling stage of waste textiles was found when actively performing the scientific processes for the dissolution of cellulose. The design practice at this stage did not deviate from the scientific method that was applied in the laboratory in order to engage with the material properties and the processes as they occur (Figure 3). Participant observation identified the raw material state in which the design practice would intervene: the cellulose dissolution before this is being regenerated into a new form [42].

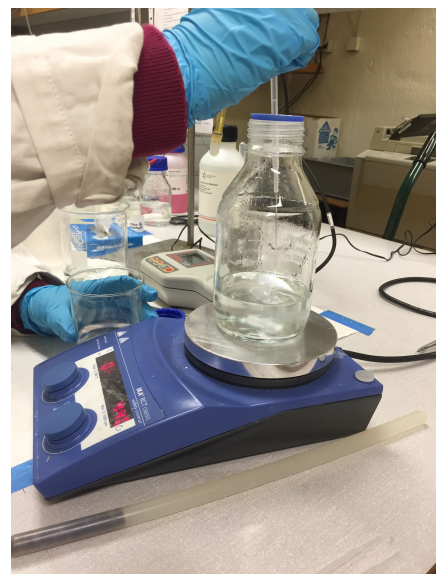

(a)

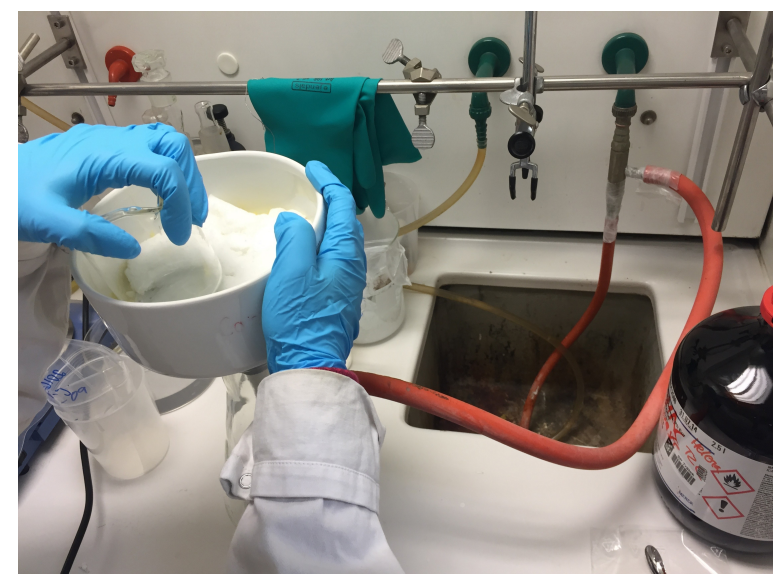

(b)

Figure 3. (a) Cellulose pre-treatment preparation during the first residency at RISE Research Institutes of Sweden; (b) Pressing and dewatering post-consumer cotton for dissolution.

\subsection{Mapping Design Interventions}

The exploration stage in the first design research residency aimed "to map how design can intervene in the production processes for regenerated cellulose in the scientific laboratory" [10] (p. 365). Interfering with scientific methods involves a high cost due to 
the people, time, and resources involved [53]. Non-invasive design interventions that do not disrupt the fibre spinning process in scientific research had to be found. Making a film was found to be a suitable process that designers can explore, with a cellulose dissolution that is unsuitable for fibre spinning [43]. Regenerated cellulose films can be produced with shortened cellulosic fibres that are obtained from textiles waste using a cellulose dissolution with a lower degree of polymerisation that cannot be spun into fibres [42]. Researchers may extrude, mould, or dry a regenerated cellulose film following a scientific method, and these are techniques which can be explored through design. Tools and techniques for moulding the films were explored both with regenerated cellulose in the materials science laboratory and with bioplastics with similar properties in the studio practice when access to the laboratory or the material was unavailable due to cost or time constraints [43]. The results were documented with photography, a sketch book, or a "material diary" [56] (p. 131), and through the resulting samples.

\subsection{Process Benchmarking}

Process benchmarking was developed from "material benchmarking" [1] (p. 41), which places the material in a context of similar materials, their applications, and experiential properties. The benchmarking of processes in the MDTD methodology places regenerated cellulose films into a context of similar cellulose-based materials in order to identify different processes that employ this material and whether textile qualities can be achieved by working with such processes. The literature and practice review of current applications in both science and design found that films in materials science are considered for packaging applications [40], not for textiles, in order to achieve a sustainable replacement of cellophane and its properties [57,58], through extrusion and casting into equal flat shapes $[57,59,60]$. In textile design, regenerated cellulose film making is not explored outside of the materials science laboratory. Processes are evidenced in printing onto film in packaging applications [33] or in other cellulose-based materials for garment moulding [61], extrusion for architectural structures [62], extrusion of textile yarn [63], and reactive properties of 3D-printed cellulose film shapes [64]. The results of these processes are flexible, transparent films that lack haptic and visual textile properties.

\subsection{Practice: Material Tests}

Material testing, through participation in the scientific research, facilitated the designer's knowledge of the scientific methods and understanding of how to work effectively with them. Process benchmarking informed the planning of the design tools and techniques for the material experiments. Textile design techniques for moulding were introduced in order to form the film into a range of shapes. The moulds were selected and developed to generate textile structures such as nonwovens and nets (Figure 4a). After producing a series of thin round films, a suitable scientific method for material testing was established. The objective of experiment 1.2, which represents the second experiment in the first residency, was to test this method in a moulding technique. The materials used were a cellulose source of post-consumer cotton provided by the laboratory and the ionic liquid solvent 1-Ethyl-3-methylimidazolium acetate (EmimAc) to dissolve the cotton at $70{ }^{\circ} \mathrm{C}$ with a dissolution of $8 \%$ cotton in the solvent. The tool introduced for moulding the cellulose dissolution was a flexible aluminium mesh (Figure 4 b). The resulting film was regenerated in a water-based coagulation bath and dried in an oven for controlled heat (Figure 4c). The qualitative assessment evidenced that the film bonded to the edges of the metal grid and broke when being removed. The film shrank when dried. It is hard, brittle, transparent and with a texture similar to plastic (Figure $4 \mathrm{~d}$ ). The success criteria showed that the film can be moulded into a fine lace-like shape but evidenced that a different method for regeneration needed testing in order to achieve flexible films. The first experiments identified bonding and moulding design techniques for exploring the cellulose dissolution through design. 


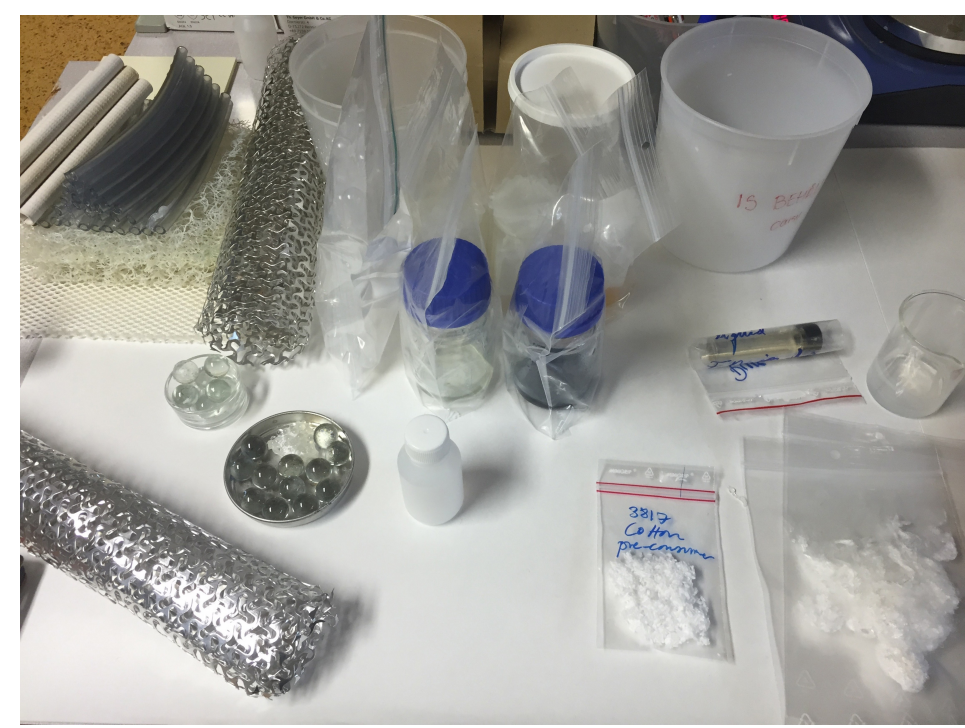

(a)

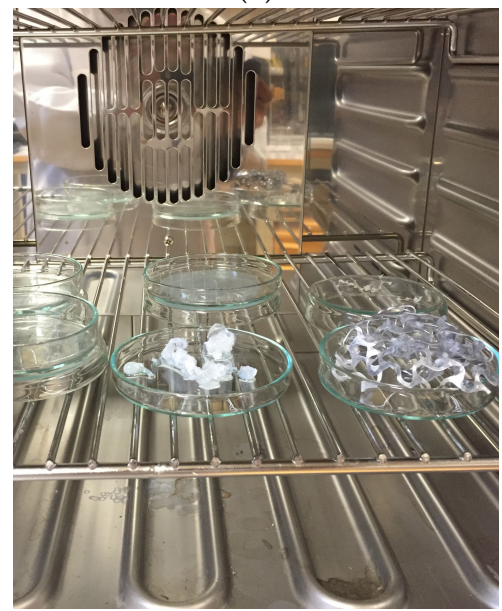

(c)

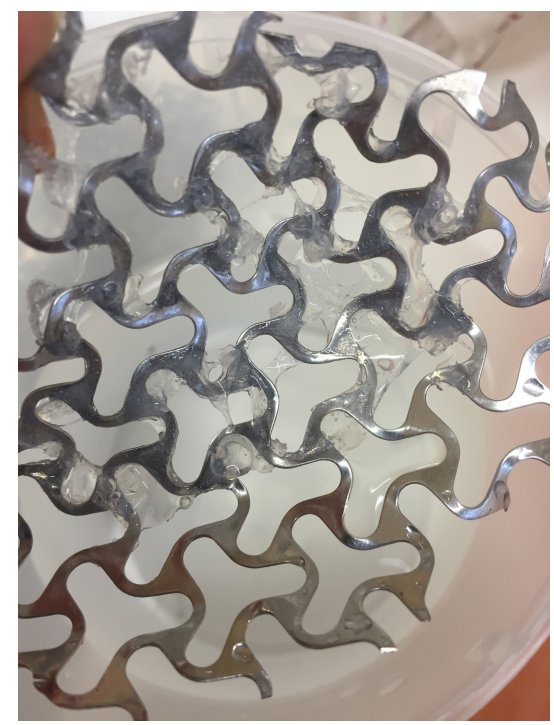

(b)

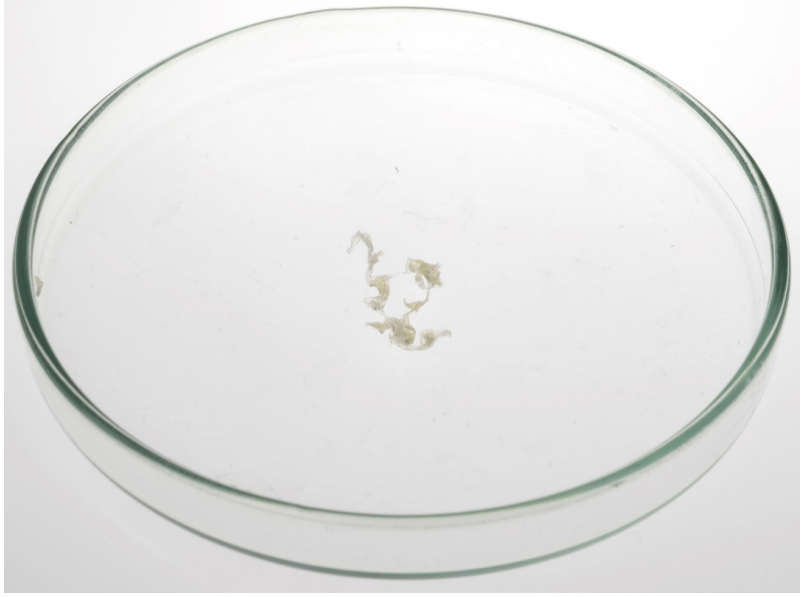

(d)

Figure 4. (a) Preparation of tools, materials, and moulds for material testing during the first residency at RISE Research Institutes of Sweden; (b) Experiment 2.1. Aluminium mesh for moulding the cellulose dissolution; (c) Regenerated cellulose samples drying in the laboratory oven; (d) Experiment 1.2. Regenerated cellulose lace-shaped film.

\section{MDTD Action Step 2: Translation}

The translation stage occurred during the second residency at RISE. The translation stage brief outlined how textile design techniques are introduced into the regeneration stages of cellulose, "to explore prototyping with regenerated cellulose films in the science laboratory for a [ . . . new value] chain for textiles from raw material to product" [10] (p. 363). The transdisciplinary methods and the development of the translation stage are further described in Ribul and de la Motte [43]. Both experiments in this stage considered "visualising" the material properties and behaviour at a tangible scale using existing design techniques, as well as the scientific method to "validate" the results with repeatable and shareable processes in the context of the circular economy [43]. The result is a technical material archive that demonstrates the prototyping possibilities with the material and the development of a transdisciplinary material design practice between the two disciplines [43]. The translation stage considered circularity in the material's "past", where the results of the experiments were compatible with the raw material state. Mono-material approaches informed the decisions in the design techniques for the material experiments, as well as the options for disassembly in order to remove any added material at the end of life. 


\subsection{Visualisation}

Before the material experiments began, a wide set of design tools and techniques informed by the textile design disciplinary background was planned in the design studio in order to establish various haptic and visual properties (such as flexibility, texture, or colour) with regenerated cellulose films in textile fabrication and finishing processes. The techniques introduced to visualise the properties of regenerated cellulose included moulding, 3D printing (Figure 5a), bonding, and coating. Each technique demonstrated the limitations of the scientific method in the design techniques: for example, a failed experiment resulted in a material breaking or an extruded dissolution cellulose regenerated on impact in a coagulation bath (Figure $5 b$ ).

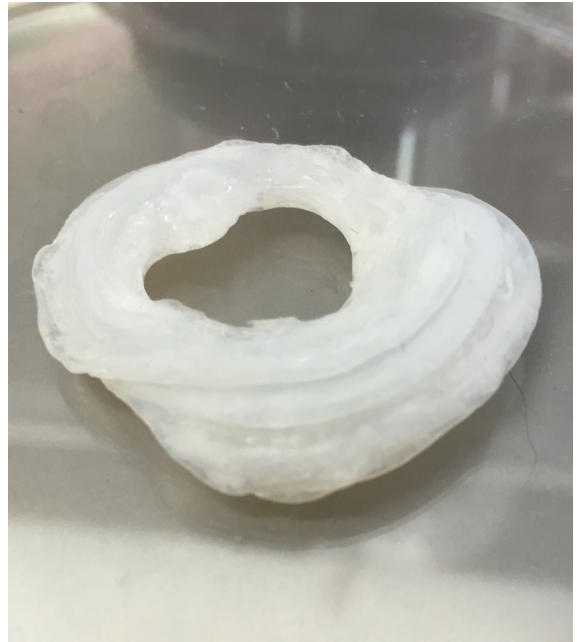

(a)

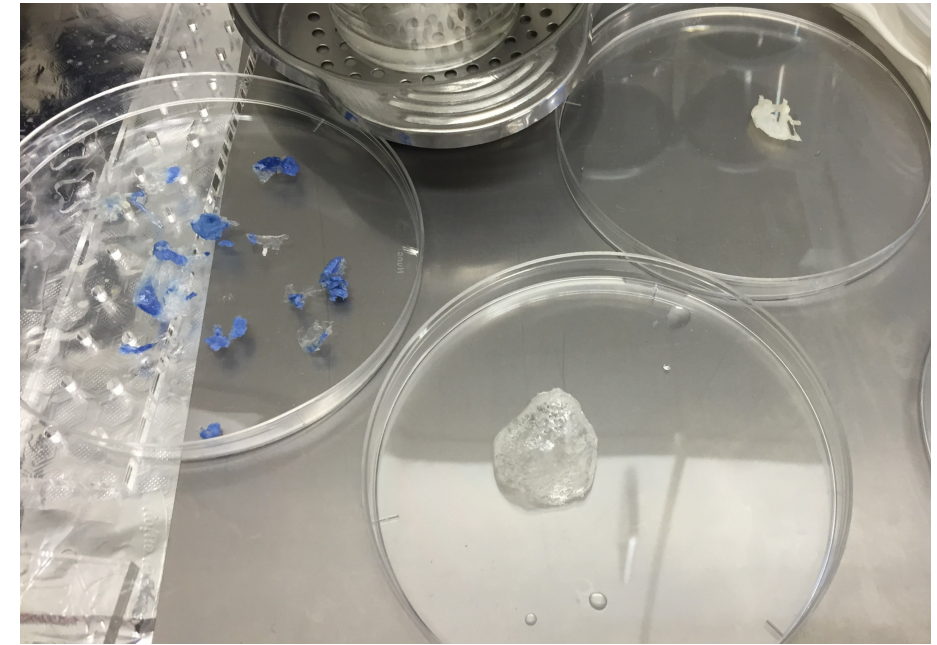

(b)

Figure 5. (a) Sample showing a three-dimensional extrusion of regenerated cellulose; (b) Three samples resulting from experiments including extruded regenerated cellulose that coagulated on impact.

\subsection{Validation}

The validation of the material experiments was informed by materials science in the following stages: (1) by adopting the scientific method in the design techniques, and (2) by documenting the experiments with a lab book. It was pertinent to the translation stage that material experiments occurred in the materials science laboratory and that they used the material that is the focus of the research. The validation of the experiments with regenerated cellulose repeated the scientific method by introducing variables such as different waste textiles, solvents, and settings in order to find the most suitable one for applying textile techniques [43]. A method was found that creates flexible films, which was then also utilised in residency 3 . The method showed which design techniques can be introduced at the raw material stage and identified where techniques should be discarded or adapted.

\subsection{Practice: Material Experiments}

The material experiments followed a similar approach to the "exploration" [21], or the first step of the "Material Driven Design (MDD)" method in the technical characterisation of the material by tinkering [1]. In the MDD method, the technical stage is followed by focus groups and interviews to map the "experiential characterization" [1] (p. 41) that the material may elicit in products. This was not the case in the translation stage, where the material experiments progressed towards textile processes with a "knowing-in-action" and "reflecting-in-action" approach [46] (p. 49) to evaluate the "sensoaesthetic" [7] (p. 69) properties of the results.

The objective of experiment 2.13, which represents the 13th experiment in the second residency, was to mould the cellulose dissolution into a three-dimensional form. An un- 
dyed $100 \%$ post-consumer cotton textile provided by the laboratory was dissolved using the ionic liquid 1-Ethyl-3-methylimidazolium acetate (EmimAc) at $80^{\circ} \mathrm{C}$ with a dissolution of $5 \%$ cotton in the solvent. An additive of sawdust was introduced in order to create texture and colour, and the tool used in the design technique was a three-dimensional plastic mould (Figure 6a). The dissolution was then regenerated in an ethanol coagulation bath and air-dried on a metal mesh. The qualitative assessment evidenced that the composite shrank less when drying and kept the shape of the mould, while the sample looks like wood and feels like paper (Figure 6 b). This result informed further testing of moulded films with additive particles in order to reduce shrinking in three-dimensional mono-material composites. The translation stage identified four mono-material design techniques for the circularity of the material: colour, texture, print, and form [10].

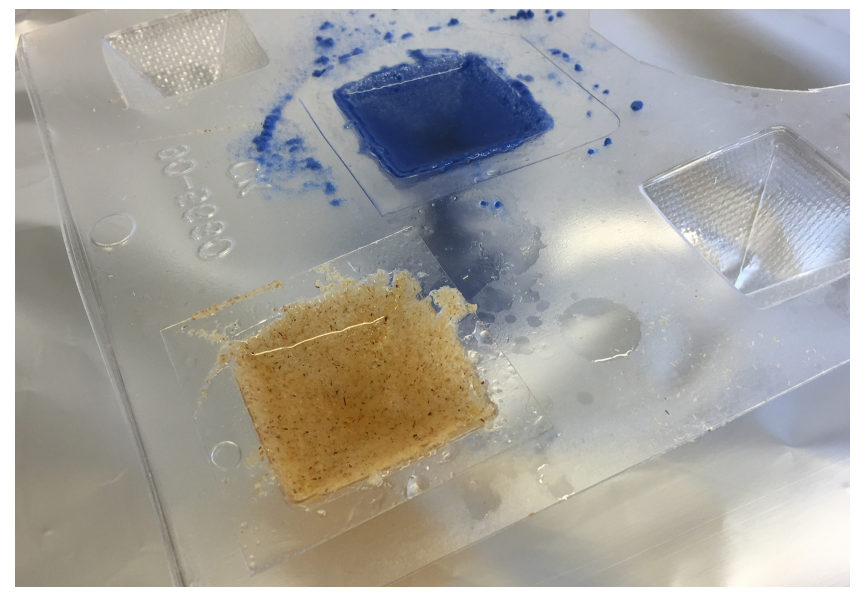

(a)

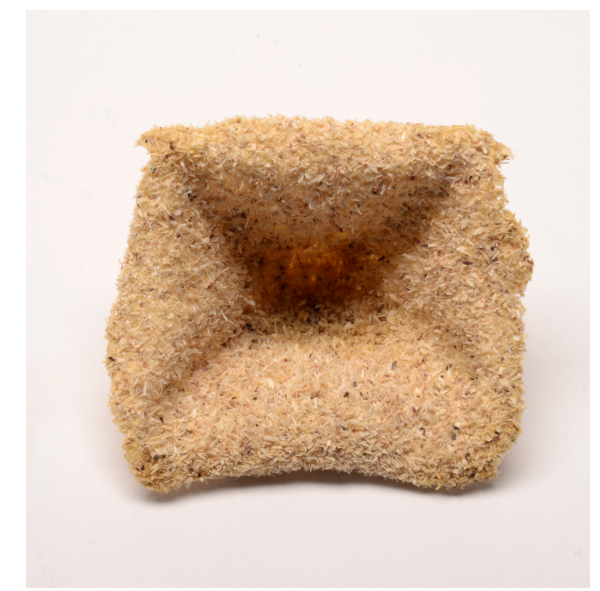

(b)

Figure 6. (a) Experiment 2.13. Plastic mould for 3D moulding; (b) Experiment 2.13. 3D-moulded film with sawdust.

\section{MDTD Action Step 3: Activation}

The activation stage is the final action step in the MDTD methodology. Here, the findings from the exploration and translation stages informed the Material Design Visions for new textile processes using regenerated cellulose materials obtained from waste textiles. An iterative cycle of design prototyping took place in the third residency at Aalto University's School of Chemical Engineering, in order to develop tangible textile or material artefacts that act "as an embodiment for a hypothesis, realizing the conditions (independent variables) in an experiment" [65] (p. 95), and materialise a possible future with a material design process that can be evaluated against textiles resulting from existing processes. The aim of residency 3 was, "to create a range of textile samples and artefacts that emerge from a practice with regenerated cellulose materials at the intersection of design and science that demonstrate [ . . new] textile processes for the circular bioeconomy" [10] (p. 367). The literature review and process benchmarking in the exploration stage established whether new processes with the material have been achieved. In this final stage, a "future" circularity perspective informs design processes that consider working with materials with modified properties after mechanical or chemical recycling has taken place.

\subsection{Material Design Visions}

According to Verganti, "envisioning" occurs when a designer creates new meanings with their design [18] (p. 180). In the MDD method by Karana et al. [1] (pp. 42-43), a "Material Experience Vision" is the second action step after the technical and experiential material characterisations have been completed. The properties of chemically recycled cellulose in existing design techniques in the translation stage informed the development of Material Design Visions for processes that manifest new forms of "material design" in a transdisciplinary domain. The envisioned techniques synthesised the results from the 
previous two action steps: (1) the properties of the material in the exploration stage, and (2) the circular design techniques in the translation stage. Four Material Design Visions were formed for processes and haptic and visual properties that are distinguished from existing developments in this field: textile shape and surface manipulation; nonwoven textile fabrication; colour in the finishing process; and 3D-moulded composites. Prototyping tools were prepared in the design studio practice in response to the envisioned textile techniques.

\subsection{Design Prototyping}

If the aim of design is "creating something that does not yet exist (either knowledge or product) and that fits into the future", then prototypes help to visualise this new paradigm and to communicate it in a tangible way [65] (p. 85). Prototypes in research can validate an idea and are often used for "testing a theory" or a "hypothesis" [65] (p. 95), but can also play a role in "reflecting on open-ended exploration" [65] (p. 87). The aim of the prototyping in the activation stage was to develop new textile fabrication and finishing processes with regenerated cellulose. The prototyping process in itself generated concrete information about the design to optimise the envisioned textile techniques and to establish the desired material outcomes. The results of the experiments were therefore qualitatively evaluated against the haptic and visual properties of textiles such as texture, form, strength, lightness, drape, colour, composition, and thickness.

\subsection{Practice: New Material Design Processes}

The final set of experiments produced artefacts that demonstrate the change in the textile processes obtained through the action research carried out in the materials science laboratory at RISE. The experiments followed the scientific method described in Section 4.3, except for the use of the Ioncell solvent, which was developed and patented at Aalto University [66]. Prototyping either proved or disproved the hypothesis of the Material Design Visions and refined the techniques employed for creating the final artefacts. For example, the envisioned 3D-moulded composite technique was discarded due to the fact that the experiments from the translation stage could not be validated using the Ioncell solvent. Prototyping, in turn, achieved a new process to fabricate a flexible textile composite. The composite fabrication process in experiment 3.26, which represents the 26th experiment in the third residency, used the same $100 \%$ post-consumer cotton waste used in experiment 2.13 and described in Section 4.3, the Ioncell ionic liquid to dissolve it, and an additive of recycled black cotton fabric. The objective of the experiment was to form a composite that has haptic and visual textile properties such as drape, handle, lightness, and breathability. A modified textile printing technique was developed to deposit the cellulose dissolution [67], which was regenerated in a water-based coagulation bath, and the result was dried in a humidity-controlled cabinet for $54.15 \mathrm{~h}$, with humidity ranging from $50 \%$ for $20.15 \mathrm{~h}$ to $25 \%$ for $29 \mathrm{~h}$ and $10 \%$ for $5 \mathrm{~h}$. The assessment of qualitative properties revealed a cellulose-based textile composite that feels soft and light and can be draped, breaking slightly at the edges (Figure 7). The success criteria evidenced the impact of the drying method on the outcome, informing further experiments. The practice-based work with the cellulose dissolution in the materials science laboratory established four new processes as the result of the methodology, which comprise two fabrication and two finishing processes $[10,67]$. Each one of these processes evolved in parallel to the others, in response to the three residencies starting from the exploration of material tests, followed by the translation of material experiments, and finally the activation of new processes through prototyping. 


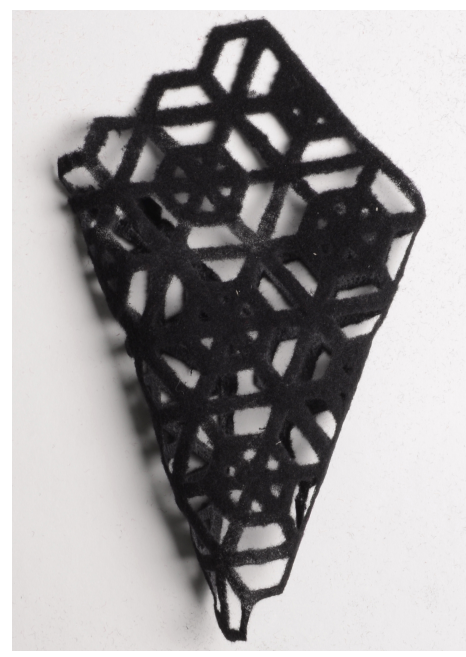

(a)

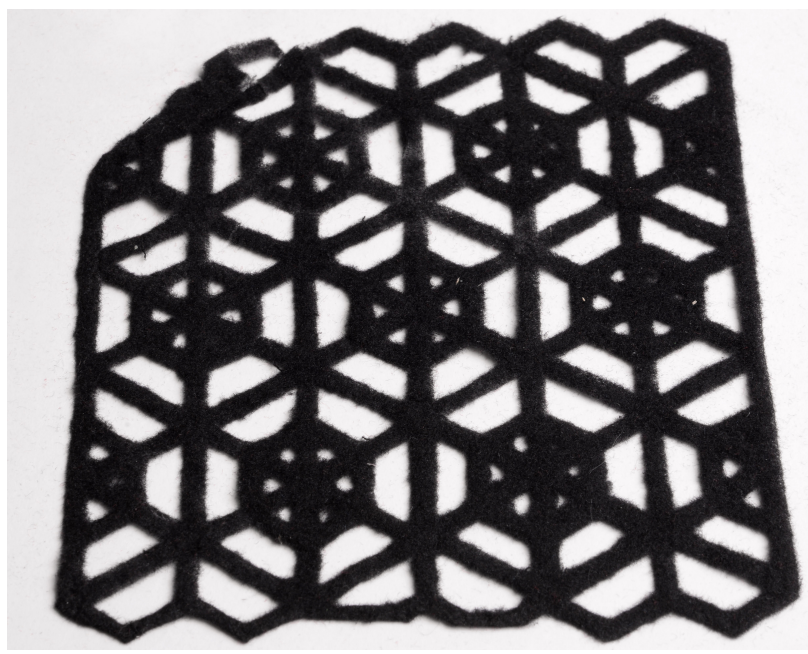

(b)

Figure 7. (a) Experiment 3.26. Textile composite folded onto itself; (b) Experiment 3.26. Textile composite.

\section{Discussion}

This paper has presented the author's Material-Driven Textile Design (MDTD) methodology, which enables designers to test, experiment and design new material design processes at the "raw" stage of their scientific development. This methodology was developed and applied with an investigation of regenerated cellulose obtained from waste textiles in the context of the circular economy. As opposed to making a "material selection" for specific end products [21], the design practice presented in this paper starts from an exploration "with" the material, proceeds with a "translation" of the design-science practice and results in an "activation" of new material design processes. The MDTD methodology offers the opportunity to go beyond an "exploration" of materials close to their raw form. Moreover, it offers an effective practice-based approach leading to new material design processes that are scientifically validated and where the haptic and visual properties of the results can be evaluated against existing processes in textile design.

Table 2 evaluates constituent elements of the MDTD methodology in the context of interdisciplinary research projects (described in Table 1). The MDTD methodology distinguishes itself from existing material design methodologies in that it integrates design practice into scientific development and the scientific method into design practice. The methodology lifts the boundaries of separated disciplinary domains, in which materials science and design usually operate, and establishes a setting in which design participates in scientific research for material development "in situ", enabling a new transdisciplinary practice to emerge. Primarily, the MDTD methodology creates a new methodological framework in which the material at hand and its properties at their "raw" stage are the drivers that inform new material design processes, decoupled from envisioned products or applications in the prevalent hylomorphic model of design. In this context, the designer's and the scientist's role does not aim for material or product development, but instead, the practice "with" the material results in new processes that inform new models for fabrication and finishing. The context of a circular economy requires a reframing of the common model of like-for-like replacement in scientific material development, in order to make new, regenerative approaches possible.

Table 2. Drivers, action steps, setting, outcomes, and practice in the MDTD methodology.

\begin{tabular}{cccccc}
\hline $\begin{array}{c}\text { Author and } \\
\text { Year }\end{array}$ & $\begin{array}{c}\text { Title (If Named) and } \\
\text { Driver }\end{array}$ & First Action Step & Setting & Outcomes & Practice \\
\hline $\begin{array}{c}\text { Ribul, 2019 } \\
{[10]}\end{array}$ & $\begin{array}{c}\text { Material-Driven Textile } \\
\text { Design (MDTD): Material } \\
\text { in its raw state and its } \\
\text { properties }\end{array}$ & $\begin{array}{c}\text { Exploration: participant } \\
\text { observation, mapping } \\
\text { design interventions, and } \\
\text { process benchmarking }\end{array}$ & $\begin{array}{c}\text { Based within the } \\
\text { materials science } \\
\text { laboratory }\end{array}$ & $\begin{array}{c}\text { New material design } \\
\text { processes "with" } \\
\text { materials at their raw } \\
\text { stage }\end{array}$ & $\begin{array}{c}\text { Transdisciplinary, } \\
\text { fluid integration of } \\
\text { design and materials } \\
\text { science practice }\end{array}$ \\
\hline
\end{tabular}


The MDTD methodology resulted in new textile processes inscribed within the circular economy, including the process for textile composite fabrication presented in this paper. Circular and regenerated materials can have properties that make them unsuitable for established processes and applications. The application of the MDTD methodology to a material in scientific development different from the one described in this paper will have different limitations and opportunities for design to intervene and develop new processes. Each "raw" material will require an in-depth exploration before new processes can be activated. These materials could be related to the disciplinary practice of designers or present unexplored starting points.

Challenges arising from the application of the methodology by other designers may be three-fold. The first challenge is that the experiments "with" materials in the three action stages depend on the tacit knowledge from a broad range of techniques of the designer, resulting from previous design projects. The second challenge is to avoid defining products or applications "of" the material early on, which could be explored only after the activation stage is completed. The third challenge is that designers may limit themselves to the exploration stage and focus solely on material tests. Without the translation stage, the designer may not identify a range of design techniques and develop a transdisciplinary practice. Similarly, the exploration and translation stages alone would hinder the development of new design processes.

The materials science context in the MDTD methodology is imperative. A designer can mimic scientific processes, but tools or materials may not be available, leading to speculative outcomes. Embedding the design practice into a materials science laboratory is recommended even if in the form of short visits and testing, whilst complementing the research with studio practice to anchor the new processes and results in the design disciplinary domain. The challenges here can lie in designers establishing collaborations with materials scientists, access, time, and costs in order to develop new material design processes, which may lead to the adaptation of the three action stages, as well as to new methods applied by each designer in order to achieve results. On the other hand, the designer's disciplinary background and tacit knowledge may adapt and change the methods and stages in this methodology.

\section{Conclusions}

The methodology described in this paper makes a compelling argument for designers to be active in the materials science laboratory in order to establish new circular materialdriven fabrication and finishing processes. Having created and applied the methodology in the context of an investigation of regenerated cellulose and its changing properties in circularity over an extended period of time, the research led to a transformation of the practice in interdisciplinary design and materials science collaboration into one that integrates discipline-specific methods. The methodology was structured into three action stages-exploration, translation, and activation corresponding to three research residencies, each with its own set of methods. The significance of these three action research stages lies in their enabling of new courses of action for materials originating in the materials science laboratory beyond established textile processes and applications. The cellulose-based composite revealed a new textile fabrication process with regenerated cellulose in a circular lifecycle, that is mono-material and compatible with the raw material stage while achieving textile haptic and visual properties. The possible context of use of this textile composite and its potential applications could form a future research project stemming from this research using another methodology. The MDTD methodology and its development are described in this paper in order to support designers who wish to move into a scientific domain whilst retaining their core design knowledge. Its application by other designers would enable a transdisciplinary practice for working "with" materials in their raw state and enable design for circularity in future textile recycling contexts. 
Author Contributions: Conceptualisation, M.R.; methodology, M.R.; validation, M.R.; formal analysis, M.R.; investigation, M.R.; resources, M.R.; data curation, M.R.; writing—original draft preparation, M.R.; writing-review and editing, M.R., K.G., and C.C.; visualisation, M.R.; supervision, K.G. and C.C.; funding acquisition, M.R. and K.G. All authors have read and agreed to the published version of the manuscript.

Funding: The PhD research was funded by the AHRC London Doctoral Design Centre (LDoC) at the University of the Arts London (UAL).

Institutional Review Board Statement: The study was approved by the Ethics Committee of the University of the Arts London (27 January 2016).

Informed Consent Statement: Informed consent was obtained from all subjects involved in the study.

Data Availability Statement: The data presented in this study are available on request from the corresponding author. The data are not publicly available due to the embargo on the Ph.D. Thesis of the author at the time of publication of this article.

Acknowledgments: With thanks to the Centre for Circular Design at Chelsea College of Arts (UAL), where this PhD research was based, to Hanna de la Motte and to RISE Research Institutes of Sweden, for hosting two research residencies, and Aalto University for supporting the third residency with laboratory space and materials for prototyping.

Conflicts of Interest: The authors declare no conflict of interest.

\section{References}

1. Karana, E.; Barati, B.; Rognoli, V.; Zeeuw van der Laan, A. Material driven design (MDD): A method to design for material experiences. Int. J. Des. 2015, 9, 35-54.

2. Boston Consulting Group. Global Fashion Agenda. The Pulse of the Fashion Industry. Available online: https://www. copenhagenfashionsummit.com/wp-content/uploads/2017/05/Pulse-of-the-Fashion-Industry_2017.pdf (accessed on 19 May 2017).

3. Ellen MacArthur Foundation. The New Plastics Economy: Catalyzing Action. Available online: https:/ / www.ellenmacarthurfoundation. org/publications/new-plastics-economy-catalysing-action (accessed on 14 March 2017).

4. Kääriäinen, P.; Tervinen, L. (Eds.) Lost in the Wood(s): The New Biomateriality in Finland, 1st ed.; Aalto University: Helsinki, Finland, 2017.

5. HM Government. Eight Great Technologies: Infographics. Available online: https://www.gov.uk/government/uploads/ system/uploads/attachment_data/file/249255/eight_great_technologies_overall_infographic.pdf (accessed on 23 October 2017).

6. Küchler, S. Materials: The story of use. In The Social Life of Material: Studies in Materials and Society, 1st ed.; Drazin, A., Küchler, S., Eds.; Bloomsbury Publishing: London, UK, 2015; pp. 267-282.

7. Miodownik, M. Toward designing new sensoaethetic materials: The role of material libraries. In The Social Life of Material: Studies in Materials and Society, 1st ed.; Drazin, A., Küchler, S., Eds.; Bloomsbury Publishing: London, UK, 2015; pp. 69-79.

8. Manzini, E.; Cau, P. The Material of Invention, 1st ed.; Arcadia: Milano, Italy, 1986.

9. Ingold, T. Making: Anthropology, Archaeology, Art and Architecture; Routledge: Abingdon, UK, 2013.

10. Ribul, M. Material Driven Textile Design: Designing Fully Integrated Fabrication and Finishing Processes with Regenerated Cellulose in the Materials Science Laboratory. Ph.D. Thesis, University of the Arts London, London, UK, 2019.

11. Oxman, N. Age of Entanglement. J. Des. Sci. 2016. Available online: http://www.pubpub.org/pub/AgeOfEntanglement (accessed on 9 June 2016). [CrossRef]

12. Brown, H.; Cook, R.; Gabel, M. Environmental Design Science Primer. Available online: https://bfi.org/sites/default/files/ attachments/pages/EnvDesignPrimer-BrownCookGabel.pdf (accessed on 9 June 2016).

13. Cross, N. Designerly Ways of Knowing: Design Discipline Versus Design Science. Des. Issues 2001, 17, 49-55. [CrossRef]

14. Peralta, C. Collaboration between Designers and Scientists in the Context of Scientific Research. Ph.D. Thesis, University of Cambridge, Cambridge, UK, 2013.

15. Driver, A.; Peralta, C.; Moultrie, J. Exploring How Industrial Designers Can Contribute to Scientific Research. Int. J. Des. 2011, 5, $17-28$.

16. Rust, C. Design Inquiry: Tacit Knowledge and Invention in Science. Des. Issues 2004, 20, 76-85. [CrossRef]

17. Design Council. A study of the Design Process. Available online: http://www.designcouncil.org.uk/sites/default/files/asset/ document/ElevenLessons_Design_Council\%20(2).pdf (accessed on 19 July 2016).

18. Verganti, R. Design-Driven Innovation: Changing the Rules of Competition by Radically Innovating What Things Mean; Harvard Business Press: Boston, MA, USA, 2009.

19. Lloyd, P. You make it and you try it out: Seeds of design discipline futures. Des. Stud. 2019, 65, 167-181. [CrossRef]

20. IDEO.org. Design Kit. Available online: http://www.designkit.org/methods (accessed on 10 November 2015). 
21. Van Bezooyen, A. Materials Driven Design. In Materials Experience: Fundamentals of Materials and Design, 1st ed.; Karana, E., Pedgley, O., Rognoli, V., Eds.; Butterworth-Heinemann: Amsterdam, The Netherlands, 2014; pp. 277-286.

22. Ashby, M.; Johnson, K. Materials and Design: The Art and Science of Material Selection in Product Design, 1st ed; ButterworthHeinemann: Oxford, UK, 2010.

23. Rognoli, V.; Bianchini, M.; Maffei, S.; Karana, E. DIY materials. Mater. Des. 2015, 86, 692-702. [CrossRef]

24. Rognoli, V.; Garcia, C.A.; Parisi, S. The material experiences as DIY materials: Self-production of wool filled starch based composite (NeWool). Mak. Futures J. 2016, 4, 1-9.

25. Barati, B.; Karana, E.; Hekkert, P. Prototyping materials experience: Towards a shared understanding of underdeveloped smart material composites. Int. J. Des. 2019, 13, 21-38.

26. Tubito, C.; Earley, R.; Goldsworthy, K.; Hornbuckle, R.; Niinimäki, K.; Östmark, E.; Sarbach, V.; Tanttu, M. Applied DDMI: A White Paper on How Design-Driven Material Innovation Methodology Was Applied in the Trash-2-Cash Project. Available online: https: / / static1.squarespace.com/static/5891ce37d2b857f0c58457c1/t/5c74266be2c4830ed71fb71e/1551115936465/D_ 1_7-White+Paper-MCI-T2C.pdf (accessed on 4 May 2019).

27. Niinimäki, K.; Groth, C.; Kääriäinen, P. New silk: Studying experimental touchpoints between material science, synthetic biology, design and art. Temes Disseny 2018, 34, 34-43. [CrossRef]

28. Wennberg, M.V.; Östlund, Å. MISTRA Future Fashion Final Report. Available online: http://mistrafuturefashion.com/wpcontent/uploads /2019/10/the-Outlook-Report_Mistra-Future-Fashion-Final-Program-Report_31-okt-2019.pdf (accessed on 10 December 2019).

29. Dell'Era, C.; Magistretti, S.; van Rijn, M.; Tempelman, E.; Verganti, R.; Öberg, Å. The White Book: Lessons from a Four-Year Journey into Design-Driven Materials Innovation. Available online: http:/ / elearning.instituteofmaking.org.uk/uploads/dellera-et-al-2016.pdf (accessed on 13 October 2016).

30. Thong, C.; Jackson, S. Microwave Modified Timber: Collaborative Research integrating Product Design for New Materials Development. Adv. Mater. Res. 2011, 284, 615-619. [CrossRef]

31. Härkäsalmi, T.; Lehmonen, J.; Itälä, J.; Peralta, C.; Siljander, S.; Ketoja, J. Design-driven integrated development of technical and perceptual qualities in foam-formed cellulose fibre materials. Cellulose 2017, 24, 5053-5068. [CrossRef]

32. Kataja, K.; Kääriäinen, P. (Eds.) Designing Cellulose for the Future. Available online: https://cellulosefromfinland.fi/wpcontent/uploads/2018/09/DWoC_Loppuraportti_FINAL_s\%C3\%A4hk\%C3\%B6inen.pdf (accessed on 21 November 2018).

33. Aalto University; VTT; Tampere University of Technology. Design Driven Value Chains in the World of Cellulose DWoC 2013-2015. Available online: http:/ / www.vtt.fi/Documents/DWoC1.pdf (accessed on 28 February 2017).

34. Design Meets Cellulose. CHEMARTS 2020. Available online: http://chemarts.aalto.fi/wp-content/uploads/2017/08/ CHEMARTS12_Collaboration.pdf (accessed on 5 October 2017).

35. Ma, Y.; Hummel, M.; Määttänen, M.; Sixta, H. Upcycling of Waste Paper and Cardboard to Textiles. Green Chem. 2015, 18, 858-866. [CrossRef]

36. Ma, Y.; Asaadi, S.; Johansson, L.; Ahvenainen, P.; Reza, M.; Alekhina, M.; Rautkari, L.; Michud, A.; Hauru, L.; Hummel, M.; et al. High-Strength Composite Fibers from Cellulose-Lignin Blends Regenerated from Ionic Liquid Solution. ChemSusChem 2015, 8 , 4030-4039. [CrossRef]

37. Östlund, Å.; Wedin, H.; Bolin, L.; Berlin, J.; Jönsson, C.; Posner, S.; Smuk, L.; Eriksson, M.; Sandin, G. Textilåtervinning: Tekniska Möjliheter och Utmaningar. Available online: https:/ / www.naturvardsverket.se/Documents/publikationer6400/978-91-620-668 5-7.pdf?pid=15536 (accessed on 5 July 2016).

38. MISTRA Future Fashion. Future Fashion Manifesto. Available online: http://mistrafuturefashion.com/wp-content/uploads/20 17/12/Future-Fashion-Manifesto-2015-1.pdf (accessed on 15 December 2015).

39. Hummel, M.; Michud, A.; Tanttu, M.; Netti, E.; Asaadi, S.; Ma, Y.; Sixta, H. High Strength Fibers from Various Ligno-Cellulosic Materials Using the Ioncell-F Technology. Available online: http:/ / costfp1205.com/wp-content/uploads/2017/schools/Documents / 3rdtrainingschool/2_Hummel_HighStrength.pdf (accessed on 20 June 2016).

40. Ellen MacArthur Foundation. Urban Biocycles. Available online: https://www.ellenmacarthurfoundation.org/assets/ downloads/publications/Urban-Biocycles_EllenMacArthurFoundation_21-06-2017.pdf (accessed on 16 September 2017).

41. Lu, J.; Hamouda, H. Current status of Fiber Waste Recycling and Its Future. Adv. Mater. Res. 2014, 878, 122-131. [CrossRef]

42. Ribul, M.; de la Motte, H. The Material Affinity of Design and Science for a Circular Economy. In Proceedings of the Circular Transitions Conference, London, UK, 23-24 November 2016; pp. 236-248. Available online: http://circulartransitions.org/media / downloads / Circular-Transitions-Proceedings.pdf (accessed on 15 January 2018).

43. Ribul, M.; de la Motte, H. Material Translation: Validation and Visualization and Validation as Transdisciplinary Methods for Textile Design and Materials Science in the Circular Bioeconomy. JTDRP 2018, 6, 66-88. [CrossRef]

44. Gustavson, B. Theory and Practice: Mediating the Discourse. In Handbook of Action Research; Reason, P., Bradbury, H., Eds.; SAGE: London, UK, 2006; pp. 17-26.

45. McNiff, J. Action Research: Principles and Practice, 3rd ed.; Routledge: London, UK, 2013.

46. Schön, D.A. The Reflective Practitioner: How Professionals Think in Action, 3rd ed.; Ashgate: Aldershot, UK, 1991.

47. Costello, P.J.M. Action Research, 1st ed.; Continuum: London, UK, 2003.

48. Simonsen, J.; Robertson, T. (Eds.) Routledge International Handbook of Participatory Design, 1st ed.; Routledge: New York, NY, USA, 2013. 
49. Heron, J.; Reason, P. The Practice of Co-operative Enquiry: Research 'with' rather than 'on' People. In Handbook of Action Research, 2nd ed.; Reason, P., Bradbury, H., Eds.; SAGE: London, UK, 2006; pp. 144-154.

50. Villari, B. Action Research Approach in Design Research. In The Routledge Companion to Design Research, 1st ed.; Rodgers, P.A., Yee, J., Eds.; Routledge: New York, NY, USA, 2015; pp. 306-316.

51. Malafouris, L. At the Potter's Wheel: An Argument for Material Agency. In Material Agency: Towards a Non-Anthropocentric Approach, 1st ed.; Knappett, C., Malafouris, L., Eds.; Springer: New York, NY, USA; London, UK, 2008; pp. 19-36.

52. Sennett, R. The Craftsman, 1st ed.; Allen Lane: London, UK, 2008.

53. Latour, B.; Woolgar, S. Laboratory Life: The Construction of Scientific Facts, 1st ed.; Princeton University Press: Princeton, NJ, USA, 1986.

54. Wilkes, S.; Wongsriruksa, S.; Howes, P.; Gamester, R.; Witchel, H.; Conreen, M.; Laughlin, Z.; Miodownik, M. Design tools for interdisciplinary translation of material experiences. Mater. Des. 2015, 90, 1228-1237. [CrossRef]

55. RISE Research Institutes of Sweden. Third Milestone Report. Available online: https://static1.squarespace.com/static/5891ce3 7d2b857f0c58457c1/t/5c0554e61ae6cfe5a110c824/1543853290648/D9.4+Third+Milestone+Report.pdf (accessed on 7 December 2018).

56. Karana, E.; Blauwhoff, D.; Hultink, E.-J.; Camere, S. When the material grows: A case study on designing (with) mycelium-based materials. Int. J. Des. 2018, 12, 119-136.

57. Wawro, D.; Hummel, M.; Michud, A.; Sixta, H. Strong Cellulosic Film Cast from Ionic Liquid Solutions. Fibres Text. East. Eur. 2014, 22, 35-42.

58. Yang, Q.; Fukuzumi, H.; Saito, T.; Isogai, A.; Zhang, L. Transparent Cellulose Films with High Gas Barrier Properties Fabricated from Aqueous Alkali/Urea Solutions. Biomacromolecules 2011, 12, 2766-2771. [CrossRef]

59. Sundberg, J.; Toriz, G.; Gatenholm, P. Moisture induced plasticity of amorphous cellulose films from ionic liquid. Polymer 2013, 54, 6555-6560. [CrossRef]

60. Hameed, N.; Guo, Q. Blend films of natural wool and cellulose prepared from an ionic liquid. Cellulose 2010, 17, 803-813. [CrossRef]

61. Designboom. Suzanne Lee: Eco Textile Fashion. Available online: https://www.designboom.com/design/suzanne-lee-ecotextile-fashion/ (accessed on 15 March 2017).

62. Duró, J.; Mogas, L. Dumo Lab. Available online: http:/ / dumolab.com/ (accessed on 7 March 2017).

63. AlgiKnit. Biology Is the Future of Fashion. Available online: https://www.algiknit.com/ (accessed on 7 March 2017).

64. Wyss Institute. 4D Printing of Shapeshifting Devices. Available online: https://wyss.harvard.edu/technology/4d-printing/ (accessed on 3 January 2017).

65. Stappers, S. Prototypes as a central vein for knowledge development. In Prototype: Design and Craft in the 21st Century, 1st ed.; Valentine, L., Ed.; Bloomsbury: London, UK, 2013; pp. 85-97.

66. Michud, A.; King, A.W.T.; Parviainen, A.P.; Sixta, H.; Hauru, L.; Hummel, M.; Kipeläinen, I.A. Process for the Production of Shaped Cellulose Articles from a Solution Containing Pulp Dissolved in Disttilable Ionic Liquids. Patent No. 2014/162062 A1, 4 April 2014.

67. Ribul, M. Future Materials Circularity: The lifecycles of regenerated cellulose in circular fabrication and finishing processes. 2021; manuscript in preparation. 